\title{
Musik Tiup dan Upacara Adat: Kasus Pengayaan Identitas Kebudayaan Musikal pada Masyarakat Batak Toba di Kota Medan
}

\author{
Mauly Purba \\ Universitas Sumatera Utara (USU) \\ Jl. Sembada VI/34 Kel. Padang Bulan Selayang II - Medan 20131
}

\begin{abstract}
Up to the 1990's the use of the gondang sabangunan, the traditional ceremonial music ensamble of the Batak Toba people, still played an important role in the practice of their adat (customary law) ceremonies-such as wedding and funeral ceremonies. In present time, however, the so-called musik tiup, a combination of Western brass instruments and Batak Toba traditional musical instruments, tends to take place of the role of the gondang sabangunan in the adat ceremonies; its use is in fact countinuous. This paper aims to investigate whether or not it is a kind of social process of forming a new musical culture identity of the Batak Toba people in Medan. Ethnomusicological and ethnohistorical approaches are used in investigating this particular social phenomenon. This research uses decriptive method and the result shows that, on one hand, the people intend to look after their ancestors' traditions through the practice of adat ceremonies where they use musik tiup, yet at the same time, they not only perform traditional gondang repertoires (gondang compositions) but also employ certain instruments of the gondang sabangunan ensamble. On the other hand, through the use of musik tiup the people mean to construct and enrich their musical culture identity.
\end{abstract}

Keywords: Batak Toba, musik tiup, Gondang Sabangunan, identity, adat

\begin{abstract}
ABSTRAK
Hingga dekade 1990an penggunaan gondang sabangunan, ensambel musik seremonial masyarakat Batak Toba Toba di kota Medan, masih memainkan peran yang penting di dalam upacara-upacara adat, antara lain upacara perkawinan dan kematian. Namun, dewasa ini ensambel yang dikenal sebagai musik tiup, yang merupakan kombinasi alat musik tiup logam (dari kebudayaan Barat) dengan alat musik dari kebudayaan Batak Toba, kelihatannya menggantikan posisi ensambel gondang sabangunan di dalam upacara-upacara adat; kondisi ini berkesinambungan. Apakah ini suatu dinamika proses sosial dalam rangka pembentukan identitas kebudayaan musikal yang baru bagi masyarakat Batak Toba di kota Medan? Pendekatan etnomusikologi dan etnohistori diaplikasikan dalam hal memahami dan menganalisa masalah ini. Penelitian ini menggunakan metode deskriptif dan hasilnya menunjukkan bahwa di satu sisi, masyarakat berusaha menjaga kesinambungan tradisi musik leluhur mereka melalui pelaksanaan upacara adat walaupun dengan format ensambel yang berbeda (musik tiup), tetapi tetap memberi ruang kepada elemen musik dan ekstra musikal tradisi gondang Batak Toba, khususnya instrumen dan melodi gondang. Di sisi yang lain, melalui musik tiup masyarakat memberikan kontribusi pada pengayaan identitas kebudayaan musikalnya.
\end{abstract}

Kata kunci: Batak Toba, musik tiup, Gondang Sabangunan, identitas, adat 


\section{PENDAHULUAN}

Paska kemerdekaan Indonesia, kemajuan di berbagai aspek sosial budaya mendorong masyarakat Batak Toba untuk keluar dari keterisolasian mereka di Tanah Batak. Setelah bermigrasi ke beberapa daerah urban di Indonesia (Medan, Jakarta, dan Bandung) di tahun 1950an, mereka mengecap pendidikan, berjuang untuk mendapatkan pekerjaan dan menghasilkan finansial serta membangun keluarga di perantauan. Kondisi ini menjadikan sebagian besar komunitas Batak Toba akhirnya menjadi komunitas yang terpelajar dan berkembang. Di kota Medan, walau tidak dominan di antara suku-suku lainnya, eksistensi komunitas Batak Toba sangatlah jelas keberadaannya. Ini dapat dilihat dari partisipasi mereka baik di lingkungan pemerintahan maupun di lingkungan swasta. Mereka terlibat di berbagai kegiatan sosial budaya, dan semua ini menegaskan peran sosial mereka di keberagaman suku dan golongan di kota Medan.

Komunitas Batak Toba adalah komunitas yang mewarisi adat leluhur. Kendati hidup di zaman modern, mereka tetap melanjutkan tradisi leluhurnya, seperti yang dapat dilihat dalam berbagai kegiatan upacara adat yang mereka lakukan sehari-hari. Upacara adat yang paling banyak mereka lakukan dewasa ini adalah ulaon adat saur matua atau ulaon adat sari matua (upacara adat kematian orang yang uzur usia) dan ulaon pangoli anak atau ulaon pamuli boru (perkawinan). Jika mereka mengacu pada pemahaman adat pada masa pra-kristen, maka seyogianya praktek upacara adat haruslah menggunakan ensambel musik tradisional Batak Toba, yaitu gondang sabangunan atau gondang hasapi dan tarian seremonialnya yaitu Tortor dengan segala perangkat lainnya, termasuk kostum ataupun tata cara penyajian gondang dan Tortor yang dikenal dalam istilah lokal sebagai adat ni gondang dohot tortor. Masalahnya adalah bahwa di kota Medan dewasa ini sulit sekali, bahkan hampir tidak pernah kelihatan lagi, masyarakat Batak Toba menggunakan ensambel gondang sabangunan di dalam upacara-upacara adat. Sebaliknya, penggunaan ensambel musik tiup dalam upacara adat sangat mendominasi dan bahkan sudah menjadi bagian yang tidak terpisahkan dari kegiatan adat dimaksud.

Bertolak dari fenomena tersebut, fokus masalah yang dikaji artikel ini, adalah pertama, apakah penggunaan ensambel musik tiup yang berkelanjutan dewasa ini merupakan suatu proses pembentukan identitas kebudayaan musikal yang baru di tengah masyarakat Batak Toba dan atau merupakan sebuah fenomena dinamika sosial yang secara berkelanjutan mencari bentuk sesuai dengan kebutuhan masyarakat Batak Toba di kota Medan pada saat ini? Kedua, apakah masyarakat Batak Toba di kota Medan melakukannya untuk pengayaan identitas kebudayaan musikal mereka? Sebagai landasan analisis di dalam memahami dan mendalami fenomena tersebut maka akan dipergunakan teori dan pendekatan etnomusikologi dan etnohistori.

\section{METODE}

Penelitian ini menggunakan metode deskriptif. Metode deskriptif adalah suatu metode untuk meneliti status suatu masyarakat, suatu objek, suatu kondisi maupun suatu sistem pemikiran, dan tujuannya adalah untuk mendeskripsikan secara lengkap tentang fakta-fakta, sifat-sifat serta hubungan antara fenomena yang diteliti (Nazir 1999: 63). Jenis data yang digunanakan adalah data primer dan data sekunder. Data primer diperoleh melalui wawancara dengan partisipan upacara, termasuk pihak yang melaksanakan upacara, pemusik, para partisipan dan pemuka adat. 
Data primer antara lain karakteristik informan, genre, gaya musik, fungsi sosial, teori praktis, tata laksana upacara adat dan pertunjukan musik. Data sekunder diperoleh melalui studi kepustakaan terhadap sumber referensi atau publikasi yang relevan, serta informasi yang dapat diperoleh lewat rekaman audio-video di lapangan maupun arkaif musik. Informan penelitian ini adalah para partisipan upacara adat (upacara kematian dan upacara perkawinan) yang menyajikan musik tiup pada upacara tersebut serta yang terjadi di kalangan masyarakat Batak Toba di kota Medan dan sekitarnya. Yang menjadi informan adalah orang yang melaksanakan upacara adat, pemusik ensambel musik tiup, serta partisipan upacara adat, termasuk tokoh yang memahami tidak saja makna adat tetapi juga ragam pelaksanaan adat di kota Medan dan sekitarnya yang dilaksanakan baik di lingkungan rumah tangga maupun di gedung-gedung pertemuan yang ada di kota Medan.

\section{HASIL DAN PEMBAHASAN}

\section{Pengertian Adat}

Ketika agama suku masih menjadi anutan utama di tengan masyarakat Batak Toba, adat dipahami sebagai rangkaian atau tatanan norma-norma sosial dan religius. Adat mengatur kehidupan sosial, manusia dengan leluhurnya, hubungan vertikal kepada sang Pencipta, serta pelaksanaan upacara-upacara ritual keagamaan. Adat tidak dapat diubah, tetapi harus dipatuhi (Tampubolon 1964 dalam Schriner 1994: 114-115). Bagi orang Batak Toba adat bukanlah sekedar kebiasaan atau tata tertib sosial saja. Adat mencakupi seluruh dimensi kehidupan: jasmani dan rohani, masa kini dan masa depan, hubungan antara si aku (sebagai mikrokosmos) dengan selu- ruh jagad raya (makrokosmos); adat adalah sesuatu yang bersifat totalitas dan merupakan pandangan hidup (Aritonang 1988: 47-48). Adat bermanfaat untuk mencegah mala petaka, menjaga keharmonisan, dan kesuburan tanah, memastikan akan adanya kesinambungan kebutuhan penduduk desa, serta menjaga keutuhan kekerabatan. Tindakan kesalahan di dalam adat atau mengabaikan adat diyakini dapat mengakibatkan ketidaksuburan tanah, datangnya wabah penyakit dan kegagalan panen (Pedersen 1970: 36). Dalam kehidupan sehari-hari, adat diwujudkan dalam banyak bentuk atau praktek: mamele sumangot (pemujaan arwah leluhur), mangongkal holi (menggali tulang belulang leluhur), dan pesta bius (upacara kurban oleh komunitas desa). Praktek ini diwariskan dari satu generasi ke generasi berikutnya sebagai bagian dari praktek adat. Praktek adat seperti ini adalah realisasi agama suku bangsa Batak Toba, yang disebut oleh para misionaris sebagai hasipelebeguan (Pardede 1987: 237-239). Dengan pertimbangan ini pula Sianipar (1972: 28-29) mengatakan bahwa antara adat dan hasipelebeguan adalah tidak terpisahkan; mereka adalah aspek yang berbeda dari dua realitas yang sama sebagai produk agama suku. Hasipelebeguan adalah suatu bentuk kepercayaan lama yang sangat bertentangan dengan iman Kristen dan oleh karena itu pula gereja sangat menolaknya, termasuk semua aspek yang melekat terhadap praktek hasipelebeguan. Dengan kata lain, hasipelebeguan adalah istilah kolektif yang merangkum keseluruhan praktik dan sifat agama suku bangsa Batak Toba (Pardede 1987:238). Termasuk dalam hasipelebeguan adalah kepercayaan pada dewa dalam mitologi orang Batak Toba, pada roh nenek moyang yang mendiami tempat-tempat sakral (Vergouwen 1986: 79).

Hingga dewasa ini masih banyak anggota masyarakat Batak Toba mempraktekkan adat di dalam kehidupan sehari-hari 
kendati mereka telah memeluk agama Kristen, memperoleh pendidikan dan hidup di daerah urban (Purba 2000: 37). Namun demikian, sikap setiap orang Batak Toba terhadap adat tidaklah sama, tetapi bervariasi. Ada yang mempraktekkan adat yang disesuaikan dengan ajaran iman Kristen. Ada yang menolak mempercayai kualitas magis adat, tetapi ada juga yang tidak tau pasti bagaimana adat harus dijalankan. Untuk sebagian orang adat bukanlah bersifat statis melainkan dinamis dan berubahubah. Sementara itu, sebagian orang tidak menginginkan adanya perubahan adat.

Dari uraian di atas dapat diambil suatu pemahaman bahwa di satu sisi adat telah berubah karena masyarakat berubah. Di sisi lain, pengertian, fungsi dan prakteknya tetap sama seperti ratusan tahun yang lalu, khususnya bagi mereka yang menjaga 'keselamatan' warisan adat leluhur. Namun tidak dapat dipungkiri, bahwa adat yang dulunya dianggap stabil dan tidak berubah telah menjadi sesuatu yang fleksibel. Pelaksanaan adat kini tergantung pada waktu, tempat, agama, dan pengetahuan serta interpretasi dari setiap pelakunya. Dewasa ini, setiap orang mempunyai opsinya sendiri tentang bagaimana ia bersikap terhadap adat, sebab adat bukanlah sesuatu yang mutlak, melainkan sebuah pilihan yang sifatnya personal.

Dalam konteks pemahaman di atas perlu dijelaskan: pertama, mengapa orang Batak Toba tetap melakukan praktek adat di era globalisasi sekarang ini? Kedua, mengapa mereka menghabiskan biaya yang tidak sedikit untuk melaksanakan upacara adat? Sebuah keluarga Batak Toba selalu terafiliasi dengan banyak keluarga Batak Toba lainnya, dalam rangkaian marganya sendiri maupun dengan marga pihak pemberi/penerima istri kepada keluarga tersebut. Melakukan praktek adat, dalam hal ini pesta adat, adalah merupakan keharusan, karena melalui praktek adat, rasa hor- mat, rasa memiliki dan rasa kebersamaan dapat dilanjutkan dan dijaga, khususnya di tempat tinggal yang sebenarnya bukan kampung halamannya. Melakukan praktek adat membantu mereka untuk merasa menjadi orang Batak Toba dan merasa satu di dalam identitas. Dalam upacara adat, melibatkan semua anggota kekerabatan adalah hal yang sangat penting, sebab kehadiran mereka (kerabat) menunjukkan kebersamaan keluarga yang harus terus menerus dijaga dan dipupuk. Di samping keluarga, maka dongan sahuta (tetangga) juga mesti dilibatkan, sebab merekalah yang menjadi penopang di dalam pelaksanaan adat. Kondisi ini menyebabkan pesta adat orang Batak Toba tidak pernah sepi partisipan, selalu ramai, baik pada upacara adat sukacita maupun upacara adat dukacita. Konsekuensinya adalah semakin ramai partisipan maka semakin besar biaya yang diperlukan, sebab pesta adat tidak pernah luput dari acara makan bersama. Kondisi seperti ini ini tidak saja terjadi di desa tetapi juga di kota-kota besar yang malah bisa melibatkan ribuan partisipan, tidak saja dalam makan bersama tetapi juga menari bersama dan berdialog dalam rangka tukar menukar hadiah seremonial. Hal ini selalu dapat dilihat di beberapa gedung serba guna yang ada di Medan, dimana 800 hingga 1000 partisipan selalu terakomodir duduk bersama dan menikmati 'pertunjukan budaya' sambil melakukan kewajibankewajiban adat. Melaksanakan pesta adat dengan skala partisipan yang relatif besar, makan bersama dengan suasana hiruk-pikuk suara orang bernyanyi dan bermain musik dibarengi orang berbicara melalui pembesar suara (loudspeaker) adalah suatu kejadian yang sangat umum sekali di tengah pelaksanaan upacara adat di kalangan masyarakat Batak Toba di kota Medan. Keadaan seperti ini adalah ciri atau identitas upacara adat masyarakat Batak Toba di kota Medan. 
Sejak dekade 60an hingga 90an jumlah komunitas Batak Toba semakin besar di kota Medan. Saat komunitas orang Batak Toba mendapat tempat bermukim, biasanya mereka akan membangun gereja serta komunitas gereja. Mereka juga membentuk organisasi marga (punguan marga) yang kegiatannya di seputar kehidupan sosial sehari-hari termasuk upacara adat yang berhubungan dengan lingkaran kehidupan. Pada tahun 1990an semakin banyak orang Batak Toba yang bermukim di kota Medan memiliki jabatan di pemerintahan, maupun memimpin perusahaan komersil dan bekerja sebagai tenaga profesional di berbagai bidang. Artinya, masyarakat batak toba telah mengalami transformasi sosial. Kendati demikian, orang Batak toba tidak lupa akan tradisi warisan nenek moyangnya. Hingga dewasa ini banyak warisan kebudayaan leluhur yang masih dipraktekkan di dalam kehidupan mereka walaupun di sana sini terdapat perbedaan dalam sikap, interpretasi maupun pengejawantahan yang mereka ekspresikan terhadap berbagai nilai-nilai kebudayaan, materimateri kebudayaan yang diwariskan nenek moyang mereka, yang selanjutnya menjadi bagian yang tidak terpisahkan dari identitas dan kehidupan sosial mereka.

\section{Tradisi Gondang Sabangunan dan Tortor}

Masyarakat Batak Toba mengenal dua jenis ensambel gondang, yaitu ensambel gondang sabangunan dan ensambel gondang hasapi. Kedua ensambel musikal ini digunakan sebagai pengiring tarian seremonial, yaitu Tortor. Ensambel gondang sabangunan adalah ensambel yang instrumentasinya terdiri dari: lima buah taganing (single headed braced and tuned-drum), satu buah odap (double headed drum $)^{1}$, satu buah gordang (single headed braced drum), satu buah sarune bolon (double- reed oboe), empat buah ogung (suspended gong), yaitu ogung ihutan, ogung oloan, ogung doal, dan ogung panggora; dan satu buah hesek atau sebuah botol kosong (struck idiophone). Keseluruhan instrumen tersebut tergabung dalam satu ensambel yang disebut dengan gondang sabangunan. Sementara itu, ensambel gondang hasapi adalah ensambel yang terdiri dari dua buah hasapi (hasapi ende dan hasapi doal) (twostringed boat lute), sebuah garantung (a wooden-xylophone), sebuah sarune etek (single-reed idioglot aerophone), sebuah sulim (transverse bamboo flute) dan sebuah botol kosong yang disebut hesek (struck idiophone).

Ensambel gondang sabangunan dan gondang hasapi memainkan repertoar musik yang sama walau berbeda di dalam warna suara dan tekstur musiknya. Kedua ensambel digunakan mengiringi Tortor pada upacara adat maupun keagamaan. Tortor adalah tarian seremonial yang disajikan bersamaan dengan penyajian musik gondang. Musik gondang dan Tortor adalah ibarat sebuah koin dengan kedua sisinya, tidak dapat dipisahkan. Kendati eksistensi kadar estika yang ada di dalam Tortor, ia bukanlah dimaksudkan sebagai karya seni semata. Tortor lebih pas diartikan sebagai bentuk pengejawantahan ekspresi, baik individu maupun kolektif, yang muncul hanya pada saat upacara adat maupun ritual. Walaupun secara fisik Tortor merupakan tarian, namun makna yang lebih dalam dari gerakan-gerakannya menunjukkan bahwa Tortor adalah sebuah media komunikasi di dalam upacara adat, di mana melalui gerakan-gerakan yang disajikan terjadi interaksi antara partisipan upacara. Hal ini dapat dilihat ketika partisipan upacara melakukan penghormatan, penyembahan, pemberkatan atau juga pemberian dan penerimaan 'hadiah' seremonial, seperti uang, ulos (selendang tenunan tradisional), beras, minuman, makanan, jambar (potongan-potongan daging sembelihan yang dibagikan kepada pihak-pihak yang 
berhak menerima sesuai kedudukannya di dalam adat) dan lain sebagainya.

Tradisi gondang sabangunan dan Tortor adalah bagian dari adat dan hasipelebeguan. Keduanya merupakan unsur penting dalam berbagai upacara yang bersifat magis dan religius. Tradisi gondang sabangunan dan Tortor, sejak masa pra-Kristen (1860an) hingga kini, masih tetap menjadi bagian integral dari adat. Memang dalam konteks adat pra-Kristen, penyajian ensambel gondang sabangunan sangat erat kaitannya dengan adat dan agama suku Batak Toba. Seperti musikologist Batak, Liberty Manik, menegaskan bahwa dalam semua upacaraupacara keagamaan maupun upacara-upacara adat, gondang sabangunan mempunyai peranan sentral. Gondang sabangunan hanya dipakai dalam pesta-pesta atau perayaanperayaan yang bersifat keagamaan atau yang berhubungan dengan adat (Manik 1977: 71-72). Aspek lain yang mempererat hubungan gondang sabangunan dan Tortor dengan adat dan hasipelebeguan adalah keberadaan adat ni gondang. Adat ni gondang adalah peraturan dan struktur penyajian gondang sabangunan dan Tortor yang merupakan warisan leluhur yang harus selalu diperhatikan. Detail-detail peraturan dan struktur ini bisa berbeda dari satu daerah ke daerah yang lain. Peraturan dan struktur tersebut mempertaut tradisi gondang sabangunan dan Tortor dengan adat dan hasipelebeguan. Aspek lain yang menguatkan hubungan antara tradisi gondang sabangunan dengan adat dan hasipelebeguan adalah penggunaannya yang sangat erat dengan praktek-praktek adat leluhur, seperti mamele sumangot, pelaksanaan pesta bius, mangongkal holi dan berbagai macam upacara yang melibatkan kekuatan-kekuatan supra natural. Tidak dapat disangkal bahwa gondang sabangunan dan Tortor, pada awalnya, hanya disajikan jika kejadian-kejadian tersebut memang berkaitan dengan adat atau ritual keagamaan. Tanpa kondisi tersebut musik gondang sabangunan dan Tortor tidak akan dipertunjukan.

Berikutnya adalah terkait status sosial musisi gondang [pargonsi]. Status dimaksud adalah suatu kehormatan yang diberikan oleh komunitas desa (partisipan upacara) kepada para musisi. Dengan kata lain, pada saat upacara adat, status sosial pargonsi berbeda dari status sosial mereka sehari-hari. Menurut kepercayaan pra-kristen, saat upacara berlangsung semua anggota pargonsi dianggap sebagai Raja Naualu, yang mewakili setiap penjuru angin (Desa Na Ualu). Lebih jauh, kedudukan dua musisi yang terdapat dalam ensambel tersebut, yaitu parsarune (peniup sarune) dan Partaganing (penabuh taganing), mempunyai predikat yang sangat tinggi. Kedua musisi itu disejajarkan dengan dewa: Panarune disebut sebagai Batara Guru Manguntar dan Partaganing disebut Batara Guru Humundul. Mengapa demikian? Karena menurut kepercayaan lama orang Batak Toba kedua musisi itu dianggap mampu menyampaikan semua permohonan/harapan para partisipan upacara kepada Mula Jadi Na Bolon (penguasa tertinggi mikrokosmos dan makrokosmos) melalui penyajian gondang.

Keseluruhan ini menguatkan bahwa begitu eratnya hubungan antara tradisi gondang sabangunan dan Tortor terhadap adat dan hasipelebeguan. Telah dikemukakan juga di atas bahwa gondang sabangunan dipandang sebagai musik sakral. Oleh sebab itu, prosedur yang mengatur penyajiannya harus diperhatikan. Keseluruhan prosedur itu tidak saja menjelaskan bagaimana gondang dan Tortor dipersiapkan dan dipertunjukkan, tetapi juga menegaskan bahwa tradisi gondang dan Tortor merupakan alat penting untuk mengejawantahkan adat dan praktik hasipelebeguan dalam kehidupan sosial orang Batak Toba. Kondisi inilah yang oleh institusi gereja ditolak dan dilarang untuk dipraktekkan oleh orang Batak Toba yang sudah mengimani ajaran Kristen. 


\section{Musik Tiup/Musik Keyboard}

Salah satu format ensambel yang sekarang lazim digunakan dalam upacara adat pada masyarakat Batak Toba di kota Medan adalah ensambel musik tiup. Format organisasi instrumen musikal dalam ensambel musik tiup bukanlah suatu format atau formasi yang mutlak. Ternyata, di berbagai daerah (lokasi penelitian) atau pada organisasi/kelompok musik yang ada, jumlah dan jenis instrumen yang digunakan di dalam ensambel musik tiup selalu bervariasi dari waktu ke waktu. Ada kalanya formasi suatu ensambel tergantung pada ketersediaan musisi; ada kalanya pula tergantung pada format apa yang diinginkan oleh yang menanggap kelompok pemusik tersebut.

Secara emik terdapat pemahaman yang berbeda tentang ensambel musik tiup. Sebagian memahami musik tiup sebagai ensambel musik yang organisasi alat musiknya terdiri dari instrumen-instrumen yang ditiup seperti trumpet (horn-aerophone), alto saxophone (single reed-aerophone)), tenor saxophone (single reed-aerophone), trombone (horn-aerophone), sausaphone atau tuba (horn-aerophone), ditambah satu unit bass drum (double-heads) atau snare drum (double heads). Kecuali sausaphone, tuba, dan drum, instrumen tiup yang disebutkan lainnya bisa saja terdiri dari satu atau dua unit, tergantung dari alat musik dan musisi yang tersedia. Di sisi lain, ada yang memahami musik tiup sebagai ensambel musik yang menggabungkan instrumen gitar elektrik (elektric bass-guitar dan electric lead guitar), sebuah electric keyboard, dan satu unit drum kit dengan satu atau lebih alat musik tiup logam, seperti trumpet dan atau saxophone. Ada juga yang memahami ensambel musik tiup sebagai ensambel musik yang formasi intrumentasinya terdiri dari key board, trumpet, saxophone, trombone, drum kit, electric guitar bass, electric lead guitar digabungkan dengan instrumen musik tradisional Batak Toba, yaitu taganing (tuned drum), hasapi (two stringed-boat lute) dan sulim (bamboo flute) yang disajikan dengan perlengkapan amplifikasi suara (sound system). Lebih jauh, terminologi 'musik tiup' bisa juga mengacu ke semua ensambel musik kecuali ensambel musik tradisional Batak Toba seperti ensambel gondang sabangunan atau ensambel gondang hasapi.

Berdasarkan pandangan yang bersifat emik ini, maka jelas sulit untuk membuat sebuah batasan yang tegas apa sebenarnya ukuran ensambel musik tiup dari sisi formasi. Oleh sebab itu, istilah 'musik tiup' sebaiknya dipahami dengan memperhatikan konteksnya. Artinya, harus dipahami bahwa istilah itu muncul sebagai suatu istilah yang membedakan ensambel tersebut dari

\begin{tabular}{|l|l|l|l|l|l|}
\hline Formasi 1 & Formasi 2 & Formasi 3 & Formasi 4 & Formasi 5 & Formasi 6 \\
\hline - Trumpet & - Keyboard & - Keyboard & - Keyboard & - Keyboard & - Keyboard \\
- Alto Sax & - Drum Kit & - Elect. bass & - Sulim & - Sulim & - Sulim \\
- Trombone & - Elect. bass & - Sulim & - Hasapi & - Taganing & - Trumpet \\
- Tenor Sax & - Elect. guitar & - Trumpet & & - Tam-tam & \\
- Sausaphone & - Trumpet & - Sax & & & \\
- Tuba & - Alto sax & - Taganing & & & \\
- Bass drum/ & - Tenor Sax & & & & \\
- Snare drum & - Taganing & & & \\
& - Hasapi & & & \\
\end{tabular}

TABEL 1

Variasi Formasi Instrumen dalam Ensambel 'Musik Tiup' 
ensambel musik tradisi gondang sabangunan atau pun gondang hasapi. Memang berbagai istilah lain juga bermunculan sesuai dengan pemahaman komunitas Batak Toba atau pun para musisi. Misalnya, ada juga istilah kisulte, yang merupakan singkatan dari keyboard, sulim dan trumpet. Ada juga yang menamakan ensambel ini sebagai keyboardsulim, atau hanya menyebutnya 'musik keyboard', kendati di dalam ensambel tersebut terdapat instrumen musikal lainnya. Kombinasi beberapa instrumen di dalam ensambel yang dikenal dengan nama 'musik tiup' atau 'musik' atau 'keyboard sulim' atau 'musik keyboard' dapat dilihat pada tabel 1.

\section{Identitas}

Apakah yang dimaksud dengan 'identitas etnis'? Anya P. Royce menegaskan bahwa 'identitas etnis' adalah merupakan gabungan dari keseluruhan rasa yang terkait dengan nilai-nilai, simbol serta kesejarahan yang memberikan penekanan identitas [karakter] dari suatu masyarakat. Lebih jauh Royce mengatakan:

"Ethnic identity is the sum total of feeling on the part of [ethnic] group members about those values, symbols, and common histories that identify them as a distinc group.... [an ethnic group is] a reference group invoke by people who share a common historical style based on overt features and values, and who, through the process of interaction with others, identity themselves as sharing that style (Royce 1989 dalam Okazaki, 1994: 12)

Nainggolan dalam bukunya, Batak Toba di Jakarta: Kontinuitas dan Perubahan Identitas menjelaskan bahwa ada dua pengertian yang mendasar tentang identitas. Pertama, identitas mengacu pada persamaan atau kesamaan yang dimiliki-oleh sekelompok orang-sehingga membuat sekelompok orang menjadi bersatu. Dengan kata lain, kesamaan itu yang mempersatukan diri mereka. Hal ini dapat dilihat ketika suatu kelompok etnis merasa bersatu karena disatukan oleh adanya unsur etnisitas yang sama, misalnya memiliki nenek moyang yang sama, sejarah yang sama, bahasa yang sama, agama yang sama, atau kekerabatan (Nainggolan, 2006: 7). Kedua, identitas mengacu pada adanya keunikan suatu kelompok etnis sehingga membedakan mereka dengan etnis yang lain (ibid). Nainggolan menjelaskan lebih jauh bahwa: “... identitas kolektif menunjuk kepada kesamaan...Identitas kelompok adalah hasil defenisi kolektif...Karena itu identitas merupakan suatu keseluruhan yang kompleks dari kepribadian manusia..." (Nainggolan 2006: 8). Selanjutnya, Royce dalam Nainggolan mengatakan bahwa: "Identitas etnik adalah suatu fenomena yang kuat. Hal ini menyangkut perasaan, di mana orang tersentuh atas cara yang khas...identitas dialami secara sadar. Kekuatan ini dirasakan dan diinterpretasikan dengan cara berbeda oleh orang baik individu maupun kelompok (Royce dalam Nainggolan, 2006: 8).

Lantas apa sajakah identitas budaya orang Batak Toba? Salah satu identitas orang Batak Toba adalah adanya nama klan yang selalu mengikut kepada namanya. Orang Batak Toba adalah penganut sistem patriakal, yaitu yang mengikut garis keturunan ayah. Ada dua sistem kekerabatan yang penting dalam masyarakat Batak Toba: (1) marga dan (2) dalihan na tolu. Marga adalah sesuatu yang berhubungan dengan silsilah keluarga. Marga mengikat seseorang dengan orang lain atas dasar garis keturunan. Sementara dalihan na tolu adalah institusi sosial yang mengikat anggota keluarga dari suatu marga dengan marga lain ke dalam suatu sistem hubungan kekeluargaan yang lebih luas, yang diakibatkan oleh adanya perkawinan di antara anggota marga yang berbeda. Marga dan dalihan na tolu adalah sistem kekerabatan yang hingga era dewasa ini masih tetap langgeng dan berfungsi dengan baik di dalam kehidupan 
masyarakat Batak Toba. Marga dan dalihan na tolu adalah substansi identitas masyarakat Batak Toba yang mengikat anggota masyarakat Batak Toba di kota Medan, bahkan di mana pun mereka berada.

Bahasa adalah sistem komunikasi. Bahasa Batak Toba adalah satu lagi substansi identitas komunitas Batak Toba di kota Medan, lewat mana anggota masyarakat Batak Toba berkomunikasi sehari-hari, baik dalam percakapan tatap muka langsung maupun lewat media telepon atau media sosial lainnya, seperti facebook, sms, dan lain-lain. Bahasa Batak Toba, kendati tidak sepenuhnya lagi digunakan oleh masyarakat Batak Toba (khususnya orang-orang muda belia) yang hidup di daerah urban seperti Medan, Jakarta, Bandung, Surabaya atau kota-kota besar lainnya, namun eksistensinya masih tetap terpelihara. Di pestapesta adat, bahasa Batak Toba masih sangat kental penggunaannya di kalangan para pelaku adat. Bahasa Batak Toba juga dipakai pada saat memberikan kata-kata nasehat dan bait-bait pantun kepada pengantin saat upacara perkawinan, kepada keluarga yang berduka saat upacara kematian, kepada pemain musik saat meminta musik untuk dimainkan, maupun saat menuturkan cerita-cerita atau kisah-kisah tertentu di pertemuan-pertemuan informal antar keluarga maupun sanak saudara. Bahasa Batak Toba juga tetap digunakan di dalam khotbah para pendeta saat kebaktian hari minggu di gereja-gereja suku yang ada di desa maupun di kota seperti di Medan. Gereja HKBP (Huria Kristen Batak Protestan), GKPI (Gereja Kristen Protestan Indonesia, HKI (Huria Kristen Indonesia) adalah beberapa gereja suku yang masih sangat konsisten menggunakan bahasa Batak Toba sebagai bahasa penghantar dalam setiap kebaktian.

\section{Pengayaan Identitas}

Identitas adalah sesuatu yang dapat berubah karena identitas merupakan suatu kenyataan sosial yang situasional. Artinya, identitas adalah sesuatu yang kontekstual. Dengan kata lain, identitas bisa berubah disebabkan oleh adanya kondisi sosial politik tertentu. Oleh karena itu suatu kelompok etnis bisa saja menciptakan identitas baru dengan mengakomodir unsur-unsur identitas baru dari tempatnya yang baru. Lebih jauh Nainggolan mengatakan bahwa ada dua faktor yang berperan dalam perubahan identitas. Pertama adalah adanya proses penyesuaian di dalam mengidentifikasi diri karena menetap di daerah yang berbeda dari asalnya. Perubahan ini tergantung apakah daerah itu memiliki kultur dominan atau memiliki tipe masyarakat tidak memiliki kultur dominan. Kedua adalah proses kreativitas, yaitu anggota masyarakat yang tinggal di suatu daerah yang bukan asalnya mengombinasikan aspek-aspek kebudayaannya sendiri dengan aspek-aspek kebudayaan lokal di mana mereka menetap (Nainggolan, 2006: 6 -10). Ini jelas akan menghasilkan sesuatu yang baru di masyarakat tersebut. Seperti Kumabara juga menegaskan bahwa:

\footnotetext{
“...identitas adalah suatu esensi yang dapat dimaknai melalui tanda selera, kepercayaan, sikap, dan gaya hidup. Identitas dianggap bersifat personal sekaligus sosial dan menandai bahwa "kita sama atau berbeda" dengan yang lain (the others). Tanda-tanda itu hendaknya tidak dimaknai sebagai sesuatu yang tergariskan secara tetap atau sui genesis, tetapi sebagai bentuk yang dapat berubah dan diubah, serta terkait dengan berbagai konteks sosial budaya dan kepentingan. Ketika tanda-tanda itu dilekatkan pada kelompok suku tertentu, dia dinamakan identitas etnis. Dengan demikian, identitas dalam konteks ini dipahami bukan sebagai entitas tetap, melainkan sesuatu yang diciptakan, sesuatu yang selalu dalam proses, suatu gerak maju daripada
} 
sesuatu yang datang kemudian, dan sebagai deskripsi tentang diri yang diisi dengan emosional dalam konteks situasi tertentu." (Kumbara, 2008: 316)

Berdasarkan uraian di atas dapat dipahami bahwa identitas adalah suatu substansi yang bisa saja diperkaya dengan simbol-simbol budaya atau kebiasaan-kebiasaan yang menumbuhkan rasa saling memiliki atau pun rasa kebersamaan di antara suatu komunitas.

\section{Musik Tiup Masuk dalam Lingkaran Upacara Adat}

Pada awal tahun 1860an Dr. I.L. Nommensen, missionaris Jerman yang terafiliasi dengan organisasi Rheinische Missionsgesellschaft (RMG) yang berasal dari Wuppertal, Jerman, berhasil mengakhiri masa isolasi orang Batak Toba. Lebih jauh, sejak 1860an hingga 1940an, Nommensen berhasil 'meng-Kristenkan' sejumlah besar orang Batak Toba yang semula adalah penganut kepercayaan leluhur Batak Toba. Bersama dengan pemerintah kolonial Belanda yang menjajah Indonesia pada era tersebut, Nommensen berhasil mengembangkan sistem pendidikan yang berbasis kebudayaan Barat di Tanah Batak. Mengikuti keberhasilan tersebut adalah kemajuan di bidang pendidikan yang selanjutnya berimplikasi mendorong perkembangan agama Kristen dan institusi gereja di kalangan masyarakat tersebut. Sebagai perkembangan lebih jauh, institusi gereja memperluas jangkauan pelayanannya dari persoalan kehidupan pribadi ke persoalan kehidupan kolektif masyarakat. Sementara memperkenalkan nilai-nilai kehidupan sosial yang baru, yaitu yang didasarkan pada ajaran iman Kristen, institusi gereja juga mencari cara untuk mengeliminasi materi maupun nilai-nilai kebudayaan tradisionil yang tidak sejalan dengan ajaran iman Kristen, terma- suk tradisi gondang sabangunan dan Tortor, dan juga sejumlah upacara ritual. Seperti yang sudah dijelaskan sebelumnya, tradisi gondang sabangunan dan Tortor adalah bagian dari adat yang kadar hasipelebeguannya sangat kental dan tidak ditolerir ajaran iman Kristen.

Keinginan institusi gereja (Protestant) di Sumatera Utara dewasa ini tentang perilaku bermasyarakat terrefleksi di dalam buku Hukum Siasat Gereja. Buku ini memberikan arahan-arahan tentang bagaimana normanorma kehidupan masyarakat Kristiani. Beberapa artikel di dalam buku dimaksud memberikan batasan yang tegas tentang aktifitas musikal anggota masyarakat Batak Toba yang sudah menganut agama Kristen Protestan, khususnya yang berkaitan dengan penyajian ensambel gondang sabangunan dan Tortor dalam konteks upacara-upacara ritual. ${ }^{2}$ Hal ini menjadi perhatian yang serius di kalangan orang Batak yang telah menganut agama Kristen. Seperti yang dikatakan oleh Harnish bahwa pada saat orientasi agama dan politik suatu masyarakat berubah para anggota masyarakat tersebut akan menginterpretasikan kembali struktur, isi dan konteks seni pertunjukan mereka (Harnish, 1992: 29-58). Demikian juga Kartomi menegaskan bahwa sebuah tradisi, akibat tekanan politik atau institusi agama, bisa juga mengalami 'proses penyesuaian' atau procces of appropriation (Kartomi 1993: 513-521). Proses ini bisa dilakukan dengan berbagai cara dan pendekatan. Esensinya adalah bahwa perubahan sosial dalam suatu masyarakat memberi dampak pada prilaku mereka-sebagai ekspresi kongkrit kebudayaannya-sesuai dengan pemahaman mereka terhadap orientasi perubahan dimaksud.

Sejalan dengan perkembangan zaman, terlebih-lebih sesudah meluasnya pengaruh Kristen dan kebudayaan Barat lainnya, maka banyak tradisi yang ada di dalam konteks adat kecuali dalam konteks upa- 
cara kepercayaan - tidak dominan lagi, dengan alasan karena "tidak sesuai lagi" dengan prinsip dan ide yang ada di dalam ajaran iman Kristen. Memperhatikan dan menyimak penyajian tradisi gondang dan Tortor pada masyarakat Batak Toba dewasa ini maka kita akan dihadapkan pada berbagai variasi dan interpretasi. Dari berbagai pengamatan di lapangan, tampak adanya usaha para penyandang tradisi itu untuk menyesuaikan kebutuhan akan tradisi tersebut sesuai dengan tuntutan institusi agama, dalam hal ini gereja. Mungkin usaha ini juga untuk menghindarkan akan adanya pemahaman bahwa pemakaian tradisi gondang dan Tortor sebagai sesuatu yang bertentangan dengan ajaran iman Kristen.

Dari pengamatan di lapangan yang pernah penulis lakukan di tahun 1990an, ada beberapa kecenderungan yang dilakukan oleh pelaku tradisi gondang dalam rangka penyesuaian-penyesuaian dimaksud di atas. Pertama, di samping berbagai interpretasi, kebanyakan elemen struktur yang tradisional tidak dilakukan lagi. Pelayanan kebaktian Kristen untuk mengawali acara adat selalu mendahului penyajian gondang dan Tortor, walaupun pada kenyataannya tidak semua mengakhirinya seperti mengawalinya. Kondisi seperti ini jelas menunjukkan bahwa di dalam tradisi gondang dan Tortor di kalangan masyarakat Batak Toba yang sudah menganut agama Kristen telah terjadi "coexistence" antara adat dan ajaran agama Kristen. Kendati sulit menentukan seberapa 'tebal' kadar masing-masing elemen, namun di lapangan hal ini sangat visibel.

Berbeda dalam pelaksanaan adat itu sendiri, dalam konteks penggunaan atau penyajian musik gondang sangat jelas adanya suatu perubahan. Adanya peringatan atau himbauan pihak gereja kepada anggota jemaatnya untuk selalu mawas diri di dalam penggunaan perangkat-perang- kat kebudayaan musikal warisan leluhur menyebabkan banyak warga gereja-yang dalam hal ini orang Batak Toba itu sendiri-yang enggan menanggap musik tradisi gondang sabangunan dan pemain musiknya (pargonsi). Namun, tanpa musik gondang, maka upacara adat akan sepi; sebab semua interaksi yang terjadi di dalam upacara adat selalu diiringi gondang. Sementara itu pelaku adat ingin terbebas dari asumsi negatif sebagai penganut hasipelebeguan jika menggunakan ensambel musik gondang sabangunan. Inilah yang mendorong komunitas Batak Toba, khususnya yang ada di kota Medan, untuk memilih atau mendorong penggunaan musik yang berbeda. Jenis musik yang paling pas dan yang kelihatannya tidak mendapat sorotan negatif adalah jenis musik yang selalu digunakan di kebaktian di gereja, yaitu musik/nyanyian himne gereja yang sudah sejak awal penyebaran agama Kristen digunakan dengan iringan instrumen organ atau ensambel musik tiup yang juga sudah lebih dulu diperkenalkan oleh para missionaris Jerman.

Sebenarnya ensambelmusik tiupbukanlah genre musik yang baru dalam konteks perkembangan musik di kalangan orang Batak Toba. Format ensambel musik ini sebenarnya berawal dari diperkenalkannya ensambel brass band, yaitu ensambel musik tiup yang semua instrumennya terdiri dari alat musik tiup logam oleh para misionaris Jerman di periode awal perkembangan agama Kristen di Tanah Batak (khususnya di wilayah Tarutung, Silindung, dan Toba Holbung (Balige). Format ensambel musik tiup tersebut ternyata menarik bagi banyak orang Batak Toba dan segera menjadi suatu bentuk musik iringan yang disukai di kebaktian-kebaktian gereja di kalangan suku Batak Toba.

Ternyata kemudian hari musik tiup tidak saja dipakai untuk mengiringi acara kebaktian di gereja, tetapi juga di pakai untuk acara 'outdoor' khususnya untuk 
mengiringi nyanyian himne gereja mana kala suatu upacara adat dibuka atau ditutup oleh pejabat gereja. Penggunaan musik tiup ternyata tidak berhenti sampai di situ. Di awal tahun 1980an musik tiup sudah banyak digunakan pada upacara-upacara adat untuk mengantikan peranan ensambel gondang sabangunan, yang nota bene masih sangat terbatas penggunaannya, sehubungan dengan adanya larangan gereja menggunakannya pada upacara adat, kecuali mendapat dukungan sepenuhnya dari gereja. Kondisi ini memang memberikan ruang yang luas kepada ensambel musik tiup untuk lebih berkembang dan berperan pada kegiatan-kegiatan sosial, apalagi yang melibatkan adat. Di satu sisi, ensambel gondang sabangunan memang musik warisan leluhur; namun menghadirkan ensambel gondang sabangunan di dalam upacara adat bukanlah hal yang sederhana. Sebab ada normanorma adat yang harus dipenuhi, sehingga membuat banyak orang di daerah perkotaan memilih penggunaan musik tiup.

Perkembangan musik tiup sangat pula didukung oleh perkembangan teknologi di bidang musik. Kreativitas orang-orang Batak Toba yang melihat peluang baik dari sisi ekonomi maupun dari sisi kreativitas, memberikan ruang bagi para pelaku musik untuk berkolaborasi. Sejumlah seniman musik gondang Batak, seperti Marsius Sitohang, Sarikawan Sitohang, Sotan Sitanggang (alm), Sijabat, dan Alister Nainggolan-yang berasal dari desa yang memiliki pengalaman panjang pada tradisi Opera Batak $^{3}$, hijrah ke kota Medan di awal dekade 1980an dan membentuk grup musik yang baru atau bergabung bersama kelompokkelompok musik tiup yang sudah ada. Mereka memberi kontribuasi yang signifikan di dalam tradisi musik tiup/musik keyboard di kota Medan, sekaligus memberikan warna yang berbeda terhadap apa yang dikenal sebagai ensambel musik Batak Toba. Perpaduan antara melodi musik Batak Toba, yang biasanya dimainkan pada ensambel gondang sabangunan atau gondang hasapi, kemudian ditampilkan dengan instrumen brass band, keyboard, drum dan electrick bass, dan penggunaan sound system. Ini jelas memunculkan warna dan idiom baru di dalam musik yang dimainkan. Perkembangan ini masih berlanjut lagi dengan penggunaan repertoar-repertoar musik Opera Batak yang dimainkan dengan penambahan instrumen hasapi dan sulim di satu sisi, dan muculnya kemudian repertoar musik populer, baik yang dimainkan secara instrumental atau pun yang dinyanyikan oleh sekelompok penyanyi, baik yang berasal dari repertoar musik Pop Indonesia dan daerah atau musik pop dari luar Indonesia, seperti India.

Penggunaan musik tiup dengan berbagai format ensambel di dalam upacara adat masyarakat Batak Toba di kota Medan bukan lagi merupakan fenomena yang baru, tetapi sudah menyatu dengan kondisi sosial budaya yang ada dan berkembang sekarang ini. Dengan kata lain, kehadiran musik tiup dalam rangka upacara dukacita atau sukacita sudah menjadi satu kesatuan. Kehadiran musik tiup/musik keyboard dengan segala keterkaitannya dengan kebudayaan populer kini menjadi substansi penting dari identitas masyarakat Batak Toba di kota Medan.

Kendati dari sudat pandang adat warisan leluhur kebiasaan menggunakan musik tiup atau musik keyboard bukanlah sesuatu yang diwariskan nenek moyang, namun ini adalah suatu kenyataan bahwa identitas bisa berubah. Jika pada awalnya musik adat adalah musik gondang sabangunan atau musik gondang hasapi, namun sekarang keadaan sudah berubah. Musik tiup memang bukan gondang sabangunan atau gondang hasapi, tetapi peran sertanya di dalam upacara adat telah memberikan kontribusi pada identitas masyarakat Batak Toba, khususnya yang ada di kota Medan. 
Seperti yang sudah diuraikan di atas bahwa identitas adalah sesuatu yang dapat berubah karena identitas merupakan suatu kenyataan sosial yang situasional. Artinya, identitas adalah sesuatu yang kontekstual. Dengan kata lain, identitas bisa berubah disebabkan oleh adanya kondisi sosial politik tertentu. Oleh karena itu suatu komunitas (kelompok etnis) bisa saja menciptakan identitas baru dengan mengakomodir unsur-unsur identitas baru dari tempatnya yang baru. Lebih jauh Nainggolan mengatakan bahwa adalah proses kreativitas yang mendorong terjadinya suatu kolaborasi, yaitu masyarakat yang tinggal di suatu daerah yang bukan asalnya mengombinasikan aspek-aspek kebudayaannya sendiri dengan aspek-aspek kebudayaan lokal di mana mereka menetap (Naingolan, 2006: 6-10). Ini jelas akan menghasilkan sesuatu yang baru di masyarakat tersebut.

Tidak dapat dipungkiri bahwa adat leluhur termasuk pelaksanaanya di kalangan masyarakat Batak Toba di kota Medan telah berubah, karena masyarakat Batak Toba di kota Medan juga mengalami perubahan sesuai kondisi sosial politik yang ada dari masa paska kemerdekaan hingga dewasa ini. Apakah sebenarnya arti adat bagi orang Batak Toba di kota Medan pada masa kini? Jelas hal ini sulit untuk dirumuskan, sebab adat bagi orang Batak Toba di kota Medan sekarang bukanlah suatu peraturan atau hukum yang baku seperti halnya di masa pra-Kristen. Adat adalah sesuatu yang akan selalu berkompromi dengan waktu, pelaku dan kebutuhan. Dewasa ini, adat bagi masyarakat Batak Toba di kota Medan adalah merupakan sesuatu yang fleksibel. Salah satu respon orang Batak Toba di kota Medan terhadap permahaman adat dewasa ini adalah bagaimana mereka menghadirkan musik dalam konteks upacara adat yang mereka lakukan di dalam kehidupan sehari-hari.

Mempelajari fakta-fakta yang ada dan menemukan korelasi antara satu fakta dengan fakta lainnya dapat disimpulkan bahwa penggunaan ensambel musik tiup pada upacara adat dengan berbagai aspek ekstra musikalnya - merupakan suatu respon masyarakat Batak Toba terhadap adat mereka sendiri. Terjadinya perubahan sikap terhadap adat leluhur dan tradisi yang ada sebelumnya (sebelum hidup di perkotaan) adalah merupakan konsekuensi logis dari kehadiran berbagai kondisi sosial yang ada di perkotaan, yang sangat memperhatikan efisiensi waktu dan biaya. Perubahan sikap terhadap adat leluhur jelas tercermin di dalam sikap dan cara orang Batak Toba melangsungkan perayaan adat. Melakukan upacara adat itu sendiri merupakan suatu keinginan orang Batak Toba di kota Medan untuk melanjutkan tradisi warisan nenek moyang mereka, di mana lewat upacara adat, sistem kekerabatan dan nilainilai kegotong royongan yang sudah ada sebelumnya dapat berkesinambungan dan terjaga dengan baik. Ini adalah satu fungsi sosial dari keseluruhan pelaksanaan adat di tengah-tengah kehidupan sosial mereka. Namun demikian, tidak pula semua pelaksanaan adat dapat dilengkapi dengan norma-norma yang ada sebelumnya. Sebagai contoh adalah penggunaan ensambel gondang sabangunan yang masih selalu dianggap memiliki afiliasi terhadap kepercayaan lama, khususnya di dalam tata cara atau aturan main dalam menghadirkan musisi gondang (pargonsi) maupun dalam hal tata cara meminta gondang (mangido gondang) maupun tata cara manortor (menari) yang semuanya tergabung dalam apa yang disebut sebagai adat ni gondang. Di samping itu, pelaksanaan upacara yang dulunya memakan waktu berhari-hari kini sudah tidak jamannya lagi. Sekarang, upacara adat, kendati masih memakan waktu berjam-jam, tetapi paling tidak dapat diselesaikan dalam satu hari, bukan tiga atau seminggu. 
Kepentingan Orang Batak Toba di Kota Medan dan Pengayaan Identitas Musikalnya

Orang Batak Toba di kota Medan adalah komunitas yang peka akan lingkungannya. Banyak di antara mereka yang sukses dalam pendidikan, ekonomi dan kedudukan yang secara ekonomi telah mencapai taraf mapan, namun banyak juga anggota masyarakat Batak Toba yang harus bekerja keras dalam menghidupi keluarga. Orang Batak Toba adalah sosok orang pekerja keras, hal ini tampak dari begitu banyaknya anggota komunitas Batak Toba yang tinggal di kota Medan, yang walaupun tidak seberhasil orang lain, ternyata cukup peka di dalam merespon lingkungannya. Mereka bekerja keras dalam mengelola perekonomian keluarga, baik dalam hal berusaha dengan skala kecil-kecilan seperti berdagang, tetapi ada juga yang sampai pada usaha tahap menengah. Data yang diperoleh dari lapangan menjelaskan bahwa banyak anggota masyarakat Batak Toba yang bergerak dalam bisnis jasa angkutan kota baik sebagai pemilik kendaraan ataupun sekedar sebagai sopir, ada juga bisnis dagang makanan tradisional-rumah makan yang menyediakan makanan khas Batak Toba), cathering dan demikian juga yang bergerak dalam bidang hiburan (entertainment). Ketiganya berkembang sangat pesat. Khususnya bisnis entertainment di tiga dasawarsa belakangan ini berkembang sangat pesat, khususnya sejak akhir dekade 80an hingga di dekade 90an serta di awal tahun 2000an. Ini dapat dilihat dari pertumbuhan jumlah grup musik/penyanyi yang mengisi acara di hotel-hotel atau pun yang memproduksi rekaman-rekaman dalam format kaset, $C D$ maupun $V C D$. Namun tidak kalah pentingnya adalah pertumbuhan grup musik tiup atau musik keyboard yang sangat banyak berperan pada upacara-upacara adat yang berlangsung di beberapa gedung serba guna di kota Medan. Di antara grup musik tiup yang pernah berjaya kala itu antara lain: grup Sopo Nauli, Tonggo, Medan Musik, Tambunan, Amdito, Patra Musik, Gob Siaek Mual, Rockap, Anugrah, dan Horas.

Apa yang perlu dicatat dari uraian di atas adalah berkembangnya suatu tradisi musikal yang 'baru' dalam khasanah musik orang Batak Toba di kota Medan. Perkembangan dimaksud bukanlah tentang lahirnya instrumen musikal yang baru dalam arti fisikal, melainkan suatu idiom musik yang bersifat kolaborasi, yakni bertemunya idiom musik Barat dengan idiom musik Batak Toba. Kolaborasi ini dikenal secara organisasi instrumen sebagai 'musik tiup'. Oleh karena format ensambel ini bisa berbeda-beda, maka sering namanya tergantung pada instrumen yang ada.

Seperti yang sudah diuraikan di atas, salah satu respon orang Batak Toba di kota Medan terhadap permahaman adat dewasa ini adalah bagaimana mereka menghadirkan musik dalam konteks upacara adat yang mereka lakukan di dalam kehidupan sehari-hari. Mempelajari fakta-fakta yang ada dan menemukan korelasi antara satu fakta dengan fakta lainnya dapat disimpulkan bahwa penggunaan ensambel musik tiup pada upacara adat dengan berbagai aspek ekstra musikalnya-merupakan suatu respon masyarakat Batak Toba terhadap adat mereka sendiri. Terjadinya perubahan sikap terhadap adat leluhur dan tradisi yang ada sebelumnya (sebelum hidup di perkotaan) adalah merupakan konsekuensi logis dari kehadiran berbagai kondisi sosial yang ada di perkotaan, yang sangat memperhatikan efisiensi waktu dan biaya. Perubahan sikap terhadap adat leluhur jelas tercermin di dalam sikap dan cara orang Batak Toba melangsungkan perayaan adat. Melakukan upacara adat itu sendiri merupakan suatu keinginan orang Batak Toba di kota Medan untuk melanjutkan tradisi warisan nenek moyang mereka, di mana le- 
wat upacara adat, sistem kekerabatan dan nilai-nilai kegotongroyongan yang sudah ada sebelumnya dapat berkesinambungan dan terjaga dengan baik. Ini adalah satu fungsi sosial dari keseluruhan pelaksanaan adat di tengah-tengah kehidupan sosial mereka. Namun demikian, tidak pula semua pelaksanaan adat dapat dilengkapi dengan norma-norma yang ada sebelumnya. Sebagai contoh adalah penggunaan ensambel gondang sabangunan yang masih selalu dianggap memiliki afiliasi terhadap kepercayaan lama, khususnya di dalam tata cara atau aturan main dalam menghadirkan musisi gondang (pargonsi) maupun dalam hal tata cara meminta gondang (mangido gondang) maupun tata cara manortor (menari) yang semuanya tergabung dalam apa yang disebut sebagai adat ni gondang. Di samping itu, pelaksanaan upacara yang dulunya memakan waktu berhari-hari kini sudah tidak jamannya lagi. Sekarang, upacara adat, kendati masih memakan waktu berjam-jam, tetapi paling tidak dapat diselesaikan dalam satu hari, bukan tiga atau seminggu.

Kehadiran musik tiup atau musik keyboard di dalam upacara adat di kalangan masyarakat Batak Toba di kota Medan adalah sebuah fenomena dinamika sosial yang berkembang dari waktu ke waktu. Format ini (ensambel musik tiup/musik keyboard) bukanlah format ensambel musik yang akan bertahan lama, sebab waktu berjalan terus, tegnologi berkembang terus, pemikiran orang Batak Toba juga akan berubah generasi juga akan berubah, bahkan kebutuhan akan adat juga akan berubah. Bahwa sampai kapan musik tiup akan terus mencari bentuk sesuai dengan yang diinginkan oleh masyarakat Batak Toba di kota Medan tidak dapat dipastikan mengingat ramainya bentuk-bentuk ensambel yang sudah ada. Yang pasti adalah bahwa selama kebutuhan orang Batak Toba di kota Medan masih pada jenis musik tiup seperti seka- rang ini, maka kontinuitas ensambel musik tiup beserta variannya tetap akan eksis di kota Medan; namun sebaliknya, ensambel musik tiup akan terus bertransformasi sesuai dengan yang dibutuhkan dan jika kebutuhan akan ensambel itu tidak lagi ditunjukkan oleh masyarakat Batak Toba, maka ensambel itu digantikan lagi dengan format yang lebih baru.

Apa pentingnya bagi orang Batak Toba untuk memperkaya identitas kebudayaan musikalnya? Menurut penulis, bahwa dengan cara memperkaya identitas musikalnya melalui penggunaan musik tiup yang digabungkan dengan instrumen musik tradisi warisan leluhurnya maka orang Batak Toba di kota Medan berkontribusi yidak saja di dalam melestarikan praktek adat yang sesuai dengan konteks kehidupan mereka sekarang ini, tetapi juga merajut tradisi kebudayaan musiknya dengan format yang lebih fleksibel, yaitu dapat diterima semua pihak khususnya lembaga keagamaan atau gereja.

\section{PENUTUP}

Nettl, seorang etnomusikolog, menegaskan bahwa pada abad ke dua puluh, musik telah menjadi suatu bentuk kongkrit yang menunjukkan identitas suatu masyarakat karena bentuk-bentuk ekspresi kultural lainnya sudah semakin kurang penting. Lebih jauh Nettl mengatakan bahwa ketidakjelasan kontinuitas identitas, banyak masyarakat beralih ke musik sebagai tempat untuk mempertahankan keunikan identitas kulturalnya (Nettl, 1985: 165).

Bagi masyarakat Batak Toba di kota Medan eksistensi musik tiup dan musik keyboard adalah suatu kenyataan dinamika sosial yang memberi mereka pilihan yang bersifat pengayaan antara tradisi leluhur dan tradisi kreatif. Melalu dinamika sosial ini terjadi pula pertemuan antara kreativitas dan nilai tradisi mereka sendiri. Peneri- 
maan mereka terhadap ensambel musik tiup/musik keyboard dan segala keterkaitannya dengan aspek lainnya-teknologi, budaya musik populer dan komersialisasi-menjadikan musik tiup sebagai unsur penting dalam substansi identitas masyarakat Batak Toba di kota Medan. Musik tiup menjadi begitu erat kaitannya dengan upacara adat, sukacita maupun dukacita. Lewat musik tiup dan repertoar musikalnya-yang nota bene merupakan kumpulan melodi musik tradisi gondang, musik populer Indonesia maupun manca negara dan melodi nyanyian gereja-mereka mengekspresikan nilai-nilai budaya yang mereka alami di lingkungan kehidupannya di kota. Namun pada saat yang sama mereka sebenarnya juga memberi ruang gerak yang leluasa untuk unsur-unsur tradisi leluhur masuk di dalam format musik yang lebih baru tersebut, yaitu melalui penggunaan instrumen musikal maupun lewat penyajian repertoar-repertoar musik tradisi gondang yang dimainkan dengan format ensambel kolaboratif.

Penggunaan musik tiup/keyboard pada masyarakat Batak Toba di kota Medan dari hari ke hari juga semakin berkembang. Ini memberikan peluang bagi musisi musik tiup/keyboard dan musisi musik tradisi Batak Toba untuk berkolaborasi secara musikal dan tidak saja melahirkan idiomidiom musikal yang bervariasi, musik tiup/ keyboard juga memberi peluang bagi para musisi untuk menjadikannya sebagai salah satu sumber penghasilan pribadi/keluarga, demikian juga bagi mereka yang ingin membangun bisnis dan manajemen entertainment.

\section{Catatan Akhir:}

${ }^{1}$ Penggunaan instrumen Odap dalam ensambel gondang sabangunan merupakan pilihan. Ensambel gondang sabangunan yang digunakan komunitas Batak Toba yang menganut agama Kristen Protestan cenderung tidak menggunakan instrumen ini. Sebaliknya komunitas
Parmalim - Batak Toba--yaitu komunitas yang melestarikan tradisi kepercayaan leluhur-selalu menggunakan instrumen tersebut.

${ }^{2}$ Lebih jauh tentang Kebijakan Gereja terhadap penggunaan ensambel gondang sabangunan dan Tortor pada komunitas Batak Toba yang menganut Kristen Protestan dapat dilihat pada artikel yang ditulis oleh Mauly Purba (2000): 'Gereja dan Adat: Kasus Gondang sabangunan dan Tortor dalam Antropologi Indonesia (edisi Mei - Agustus 2000) Th XXIV. No. 62 (Hal. 25 $-41)$.

${ }^{3}$ Opera Batak adalah sejenis teater tradisional pada masyarakat Batak Toba yang pada awalnya berkembang di desa si Tamiang, Samosir, pada dekade 1920an di bawah pimpinan Mr. Tilhang Gultom. Dewasa ini jarang sekali terdengar adanya kegiatan Opera Batak di tengah masyarakat Batak Toba.

\section{Daftar Pustaka}

AA Ngr Anom Kumbara

2008 "Konstruksi Identitas Orang Sasak di Lombok Timur, Nusa Tenggara Barat". Humaniora, No. 3. Vol. 20: 316-326

F.H. Sianipar

1973 'Religion and Adat'. The Southeast Asia Journal of Theolofy. 14 (1): $28-33$

Harnish, David D.

1992 "The Performance, Context, and Meaning of Balinese Music in Lombok". Forum Ethnomusicologicum, 4. Amadeus: 29-58

J. Pardede

1987 "The Question of Christianity, Islam, and Batak Culture in North Sumatra." Cultures and Societies of North Sumatra. Reiner Carle (Ed), 235-251. Berlin: Dietrich Reimer Verlag

Jan S. Aritonang

1988 Sejarah Pendidikan Kristen di Tanah Batak. Jakarta: BPK Gunung Muli

Kartomi, M.J.

1993 "Revival of Feudal Music Dance and Ritual in the Former "Spice Island" of 
Ternate and Tidore'. Culture and Society in New Order Indonesia. Hookor (Ed). Singapore: OUP

Liberty Manik

1970 'Suku Batak dengan "Gondang Batak"nya'. Peninjau. Jakarta. Lembaga Penelitian dan Studi DGI 4.1. Jakarta.

M. Nasir

1988 Metode Penelitian. Jakarta: Ghalia Indonesia

Mauly Purba

2000 “Gereja dan Adat: Kasus Gondang Sabangunan dan Tortor". Antropologi Indonesia. Indonesian Journal of Social and Cultural Anthropology. Tahun XXIV. No. 62.

Nettl, Bruno

1985 The Western Impact on World Music. New York: Schirmer Books
Pedersen, P.B .

1970 Batak Blood and Protestant Soul: The Development of National Batak Churches in North Sumatra. Michigan: William B. Eardmans Publishing Company

Schreiner, L.

1994 Adat dan Injil. Diterjemahkan oleh P.S. Naipospos. Th. Van den End dan Jan Sihar Aritonang. Jakarta: BPK Gunung Mulia

Tagor Nainggolan

2006 Batak Toba di Jakarta: Kontinuitas dan Perubahan Identitas. Medan: Penerbit Bina Media

Vergouwen, J.C

1986 The Social Organisation and Custom ary Law of the Toba-Batak of Northern Sumatra. The Hague: Martinus Nijhoff 